\title{
A Panel Data Analysis of the Validity of Uncovered Interest Rate Parity (UIRP) in Selected African Countries
}

\author{
Deebii Nwiado $^{1} \&$ Lezaasi LeneeTorbira ${ }^{2}$ \\ 1 Department of Economics, Faculty of Social Sciences, Ignatius Ajuru University of Education, Port Harcourt, \\ Nigeria \\ 2 Department of Finance and Banking, Faculty of Management Sciencees, University of Port Harcourt, Choba Port \\ Harcourt, Nigeria \\ Correspondence: Deebii Nwiado, Department of Economics, Faculty of Social Sciences, Ignatius Ajuru University of \\ Education, PMB 5047, Port Harcourt, Nigeria.
}

Received: November 26, 2013

doi:10.5430/rwe.v7n2p15
Accepted: December 15, $2013 \quad$ Online Published: November 24, 2016

URL: http://dx.doi.org/10.5430/rwe.v7n2p15

\begin{abstract}
The theory of interest rate parity (covered and uncovered) has been severally examined by scholars from different backgrounds. Results from empirical studies have been mixed. Macroeconomics of Nation States are not monolithic. These variations in macroeconomic behaviour conditions exchange rate movements and thus interest rate changes. Even temporal macroeconomic policies such as the Certificate of Capital Importation (CCI) in Nigeria and similar policy in Malaysia could distorts the application of the theory of interest rate parity across board. Given that such distortions are rift, it is difficult to obtain a perfect result for IRP (Covered or Uncovered). This paper examined uncovered interest rate parity using the methodology of applied financial econometrics of panel data in selected African countries. The result is wholesomely inconclusive. While parity is applicable between Nigeria, Kenya and Egypt, it is not the case with Botswana and Ghana.
\end{abstract}

Keywords: African countries, cointegration, interest rate parity, exchange rate, panel data, uncovered interest rate parity

\section{Introduction}

Interest rate Parity (IRP) - that is, the equality of interest rate across different countries due to adjustment in bilateral exchange rate, is an age long theory of the working of bilateral interest rates. First formally theorized by John M. Keynes (1923), stated in its most basic form, "is an arbitrage condition that must hold when the international financial markets are in equilibrium (Eun and Resnick 2001)". It represents a no-arbitrage condition under which international investors are indifferent to interest rates on investment opportunities including bank deposits available across countries. At the core of this no-arbitrage condition is the simple assumption that bilateral interest rates differential are obliterated following adjustments in forward exchange rates (CIRP) and expected spot rate (UIRP). This singular assumption drives the whole concept of Interest Rate Parity in international finance.

Several empirical works: (Lothian, J. R. and Wu, L. 2005); Juhl, T., Miles, W. and Weidenmier, M.D. 2004); (Chaboud, A.P. and Wright, J. H. 2003); (Arias, G. 2001); (Harvey, J.T. undated); (Thornton, D.T 1989) have tested the empirical reliability of the most crucial assumption (adjustment of bilateral exchange rate to equalize bilateral interest rate differential) of the theory of interest rate parity. Findings from these empirical surveys indicate not a wholesome realization of the interest rate parity theory though.

Previous works such as those listed above measure the UIRP relation using a single national currency, for example (Ray, S. 2012) used the Indian rupee against the US dollar and the Euro and (Karahan, Ö and çolak, O (2012) the Turkish lira against the dollar. This approach does not take account of the presence of heterogeneity implicit in the individual countries as does panel data analysis. Besides, repeatedly studying cross sections observations, panel data approach are better suited to analysis the dynamics of changes. This work test the validity of the UIRP theory simultaneously amongst selected regional (Africa) currencies and short term interest rates using pool time series cross-sectional data. The approach enables a better detection and measurement of effects that simply cannot be captured in pure cross-sectional or time series data. Varying behaviour of short term interest and exchange rates due 
to differential operating macroeconomics and fiscal policies are captured in observations (time series) across time. However this does not discountenance contributions of scholars as Chaboud, A.P and Wright, J. H. (2003) who has contributed immensely to the exposition of interest rate parity condition. They argued, "works but not for long". Harvey, J.T. (undated) noted, "by the end of this paper, it will be clear to the reader that there are ... factors interfering with the textbook operation of UIRP that it is exceedingly unlikely that it would ever hold in the real world".

There are two strands of thoughts in the literature on IRP condition - covered interest rate parity (CIRP) and uncovered interest rate parity (UIRP). Uncovered interest rate argues that interest bearing assets have equal return across different countries due to adjustments in bilateral exchange rates movements. It "asserts forward market efficiency" (Ray, 2012, p. 236). This paper is set to examine the extent of the applicability of the claims of uncovered interest parity condition (UIPC) amongst African countries using pool time series cross sectional data. Capital markets in African economies are imperfect following numerous confounding constraints resulting from conflicting monetary and fiscal policies. In Nigeria for instance, there exist four exchange rates market segments - the official Whole Sale Dutch Auction System (WDAS) controlled by the Central Bank of Nigeria (CBN), the interbank market segment, the bureau de change market and an unofficial parallel exchange rate segment (Black Market) traded on street corners Iheanyi Nwachukwu (2013, 15 April BUSINESSDAYP.7). The panel data approach captures these variations and thus suitable for this study.

Summarizing this work is set out as follows. Section one of this work is the introduction, section two treats the theoretical and empirical review of existing literature. Data organisation and model specifications are undertaken in section three. Section four treats detail of the work and analyses my findings, while section five is the summary and conclusions from findings.

\section{Theory and Review of Motivating Literature}

The fundamental theory underpinning uncovered interest parity argues that interest rate differential between two countries is approximately equal to expected rate of change in spot future exchange rate (Eun, E. S and Resnick, B.G 2001). The basic hypothesis upon which UIRP is built is that of perfect capital mobility which make investors around the world indifferent between holding domestic portfolios or foreign assets (Ray, S. 2012). Taking Nigeria and say Ghana as example, this relation could be express in the cross rate format as in equation (1) below;

$$
(\mathrm{N} / \phi)^{\mathrm{e}} /(\mathrm{N} / \boldsymbol{\phi})=\left(1+\mathrm{r}_{\mathbb{N}}\right) /\left(1+\mathrm{r}_{\dot{\phi}}\right)
$$

Where $(\mathbb{N} / \phi)^{\mathrm{e}}$ is the expected future spot cross exchange rate between the Nigeria naira and the Ghanaian cedi, ( $\left.\mathrm{N} / \phi\right)$ is the current cross spot rate, $r_{\mathrm{f}}$ is the interest rate available on naira deposits and $r_{\phi}$ is the rate currently offered on the cedi deposits. Rearranging equation (1) as in equation (2) below, we present the argument of uncovered interest rate from the Nigeria perspective.

$$
\left(1+r_{\sharp}\right)=(\phi / \$)\left(1+r_{\dot{\phi}}\right)(\# / \phi)^{\mathrm{e}}
$$

The left hand side of the equation is the return on domestic investment, while the right hand side of the equation is the return one could earn investing the fund in Ghana. Implicit in the equality implied in equation (2), is the assumption that the future cross rate for the Ghanaian cedi will depreciate relative to the naira. If for some reasons this does not hold, then market forces will react to bring about equilibrium of both sides of equation (2). This is the universal foundation of uncovered interest rate parity (UIRP. It is "when the no-arbitrage condition is satisfied without the use of a forward contract to hedge exposure to exchange rate risk" (Wikipedia).

Lothian, J. R. and Wu, L. (2005), however observed a "strange" behaviour of exchange rate under the floating exchange rate regime in the early 1970s. They found that countries with high interest rate tend to have their currencies appreciate instead of depreciate as theorized by uncovered interest rate parity. Lothian, J. R. and Wu, L. (ibid) state, "this UIP puzzle, known in its other guise as "the forward premium puzzle" is so well documented that it has taken on the aura of a stylized fact and as a result has spawned a second generation of papers attempting to account for its existence". This finding, good academically as it appears, takes no cognizance of the peculiarities of countries macroeconomics which affect exchange rate and interest rate. And as Eun and Resnick (2001) observed, the so call "forward premium puzzle" is an "anomaly" due to transactions cost and instances of capital control.

The "regime" of Certificate of Capital Importation (hereafter CCI) enforced in Nigeria until July 2011when it was lifted is an example of capital control. Malaysia (1978 - 2001) also had similar capital control measure (see Goh et al 2006 cited by Karahan, Ö and çolak, O (2012). Situations like these could truly impair the arbitrage process and result in deviations from IRP. The empirical failure of the theory of UIRP is blamed on a number of faulty assumptions implicit in it. Professor Harvey asserted, "the assumption of perfect capital mobility implicit in the UIRP theory is unrealisable and therefore renders UIRP empirically unrealisable". Harvey critic of UIRP is right. For 
instance, African countries financial markets are fraught with several financial market imperfections. The existences of official and parallel currency exchange markets in many African countries' financial markets and, the recently abolished CCI regime in Nigeria are cases of financial market imperfections and imperfect capital mobility capable of jeopardizing the realization of UIRP in its entirety.

Chaboud, A.P and Wright J. H (2003) on the other hand examine UIRP "over extremely short horizons" using high frequency overnight exchange rate and interest rates found that uncovered interest parity works "but not for a long". Though Chaboud and Wright (ibid) assert that UIRP holds, they acknowledged, "The hypothesis that the slope coefficient in the UIRP regression is equal to one has been tested and decisively rejected, over different horizons and for many currency pairs and sample periods". Ray, S (2012) noted that uncovered interest rate parity "rule out arbitrage opportunity", since its basic tenets argues for equalizing domestic $(i)$ interest rate and foreign $(i *)$ interest rate spread with foreign exchanged yield. Ray's finding contradicts Chaboud, A.P and Wright J. H (2003). Karahan, $\ddot{O}$ and çolak, O (2012) are of the opinion that in developing economies monetary authorities (Central Banks) have the tendency of "over reacting" to exchange rate movements. This they conclude has significant implications for deviations from UIRP condition. The Central Bank of Nigeria for instance, has in recent years severally through policy interventions, manipulated the Naira exchange rate with the US dollar. Karahan, and çolak cited empirical findings by McCallum (1994) that support monetary authority tendency to resist rapid changes in exchanges by using interest rate as a policy tool. Braden, Martin and Salmon (1998) cite Fisher et al (1990) who used current account balance/GDP ratio as a proxy for currency risk to test UIRP and found that it holds since the coefficient on current real interest rate differential equal one. But real exchange rate differential together with current account/GDP ratio explains only $3 \%$ of the quarterly movement in the spot rate of pairs of currency they concluded.

The review of literature found variations not only in opinions as to whether UIRP holds or not, but also in the methodologies and data used in validating the holding or failure of UIRP. Lots of the empirical works on UIRP are based on single point data - regressing interest rate differentials on exchange rate differentials over either very long period for example Lothian, J. R. and Wu, L. (2005) or over extremely short period Chaboud, A.P and Wright J. H (2003) overnight interest rates. UIRP is assumed to hold if the slope coefficient is 1 and the constant is zero otherwise it is assume not to hold. The other set of empirical literature, for instance Harvey (2005), assume a priori the failure of UIRP. Various variables - currency risk, imperfect capital mobility, default risk, country risk etc. are listed as explaining deviations from UIRP and structured as in equation 3.

$$
\mathrm{Z}=f\left(\mathrm{~g}, \ddot{\mathrm{O}}, X_{\mathrm{c}}, \grave{Y} \grave{i} P_{\mathrm{ex}}, \mathrm{U}, \dot{\omega}, \mathrm{b}\right)
$$

Where $\mathrm{Z}$ measures the size of the deviation from UIRP and is a function of $\mathrm{g}$, government restriction on capital flow, $\ddot{\mathrm{O}}$, is transaction cost, $\chi_{\mathrm{c}}$, country risk, Ỳi default risk $\mathcal{P}_{\mathrm{ex}}$, foreign exchange risk, $U$, agent portfolio diversification $\dot{\omega}$, forecast confidence and $\boldsymbol{b}$ the effect of sterilization. The problem with this approach is the difficulties associated with operationalizing the various variables. For instance it is fairly difficulty to measure capital restriction, currency risk, default risk, etc. Though works such as those by Fisher et al (1990) cited by Brigden, Martin and Salmon (1997) have provided near approximation for some of the variables such as currency risk, using current account balance/GDP ratio for currency risk. Besides though, factors listed as responsible for the failure of UIRP certainly do not apply universally.

Our point of departure is the application of the panel data approach. This approach combines the strength of time series data with cross sectional effectiveness. Many of the studies reviewed are single country based or focused on duration which does not pick distortions in macroeconomics. This paper will use empirical from five countries to measure the constant and slope coefficients in testing the holding or otherwise of UIRP for simultaneously testing the theory of UIRP in time series and cross section across five different countries of Africa. Besides, current literature on the holding or failure of UIRP, are extensively America and Europe, and based in macroeconomic that are absolutely orderly and obeys most of the assumptions implicit in UIRP. Thus our paper fills a yawning gap by looking at the same theory from situations where macroeconomics fundamentals are often violated and the difficulties UIRP may face holding in such situations. Our contribution also included at look at UIRP from African countries perspectives. In place of the simple single regression equation, this paper will use the pooled time series across five countries: Nigeria, Botswana, Kenyan, Egypt and Ghana.

\section{Methodology and Model Specifications}

\subsection{Data Construction}

The historical monthly exchange rates (2003 - 2012) of five selected African countries - Botswana, Kenya, Nigeria, Ghana and Egypt countries were sourced from www.fxtop.com. Cross exchange rates (exchange rate in which 
neither currency pair is the US dollar) of the selected countries were calculated against the naira using the American term quotation system. Table 1 below and appendix A show the detail calculations for the selected African countries and currencies.

Table 1. Sample currency cross exchange rate calculation

\begin{tabular}{|c|c|c|c|c|c|c|c|c|c|c|c|}
\hline \multicolumn{2}{|c|}{ NIGERIA } & \multicolumn{3}{|c|}{ BOTSWANA } & \multirow[t]{2}{*}{ DIFFERENTIAL } & \multicolumn{2}{|c|}{ NIGERIA } & \multicolumn{3}{|c|}{ CAPE VERDE } & \multirow[t]{2}{*}{ DIFFERENCIAL } \\
\hline YEAR & NAIRA & BWP & N/P CSR & N/P ESR & & YEAR & NARIA & CVE & CSR & ESR & \\
\hline 1993 & 22.07 & 2.42 & 9.106362783 & 9.0777215 & -0.028641293 & 1993 & 22.07 & 80.43 & 0.274355 & 0.273492 & -0.000863 \\
\hline 1994 & 22.00 & 2.68 & 8.193260525 & 8.1557354 & -0.037525128 & 1994 & 22.00 & 81.89 & 0.268601 & 0.267371 & -0.001230 \\
\hline 1995 & 21.90 & 2.77 & 7.898133497 & 7.8942257 & -0.003907838 & 1995 & 21.90 & 76.85 & 0.284897 & 0.284756 & -0.000141 \\
\hline 1996 & 21.88 & 3.32 & 6.583372524 & 6.5838614 & 0.000488840 & 1996 & 21.88 & 82.59 & 0.264972 & 0.264992 & 0.000020 \\
\hline 1997 & 21.89 & 3.65 & 5.994924349 & 5.9949107 & $-1.36958 \mathrm{E}-05$ & 1997 & 21.89 & 93.18 & 0.234888 & 0.234887 & -0.000001 \\
\hline 1998 & 21.89 & 4.23 & 5.179039632 & 21.850620 & 16.67158083 & 1998 & 21.89 & 98.16 & 0.222968 & 0.940714 & 0.717745 \\
\hline 1999 & 92.34 & 4.62 & 19.96760549 & 21.991488 & 2.023882654 & 1999 & 92.34 & 103.50 & 0.892135 & 0.982560 & 0.090425 \\
\hline 2000 & 101.70 & 5.10 & 19.93355634 & 21.802286 & 1.868730071 & 2000 & 101.70 & 119.69 & 0.849693 & 0.929350 & 0.079657 \\
\hline 2001 & 111.23 & 5.84 & 19.04266798 & 20.642848 & 1.600180453 & 2001 & 111.23 & 123.23 & 0.902647 & 0.978498 & 0.075851 \\
\hline 2002 & 120.58 & 6.33 & 19.05530283 & 20.421369 & 1.366065730 & 2002 & 120.58 & 117.17 & 1.029109 & 1.102885 & 0.073776 \\
\hline 2003 & 129.22 & 4.95 & 26.10590177 & 26.846453 & 0.740551085 & 2003 & 129.22 & 97.70 & 1.322604 & 1.360122 & 0.037519 \\
\hline 2004 & 132.89 & 4.69 & 28.31690044 & 27.973041 & -0.343859022 & 2004 & 132.89 & 88.81 & 1.496359 & 1.478188 & -0.018171 \\
\hline 2005 & 131.27 & 5.11 & 25.68791167 & 25.174705 & -0.513206413 & 2005 & 131.27 & 88.67 & 1.480477 & 1.450899 & -0.029578 \\
\hline 2006 & 128.65 & 5.84 & 22.04233657 & 21.555140 & -0.487196719 & 2006 & 128.65 & 87.90 & 1.463602 & 1.431252 & -0.032350 \\
\hline 2007 & 125.81 & 6.14 & 20.49386114 & 19.310883 & -1.182978587 & 2007 & 125.81 & 80.57 & 1.561526 & 1.471389 & -0.090137 \\
\hline 2008 & 118.55 & 6.83 & 17.36465587 & 21.811172 & 4.446515649 & 2008 & 118.55 & 75.28 & 1.574765 & 1.978010 & 0.403245 \\
\hline 2009 & 148.90 & 7.16 & 20.81046487 & 21.005609 & 0.195144160 & 2009 & 148.90 & 79.38 & 1.875877 & 1.893468 & 0.017590 \\
\hline 2010 & 150.30 & 6.79 & 22.12340393 & 22.771268 & 0.647863866 & 2010 & 150.30 & 83.26 & 1.805191 & 1.858054 & 0.052863 \\
\hline 2011 & 154.70 & 6.84 & 22.62270130 & & -22.62270130 & 2011 & 154.70 & 79.32 & 1.950239 & 0.000000 & -1.950239 \\
\hline
\end{tabular}

Source: Calculated by the Author

91-Day Treasury Bill rates (hereafter TB rate) of the five selected African countries were obtained from the home pages of the Central Banks of the selected countries. Uncovered interest rate parity (UIRP) assumes perfect capital markets (assumption of efficient market) and conceives individuals as been risk neutral. Given the risk neutrality assumptions and efficient capital market, interest rate differential between two countries will be equal to the changes in exchange rates - giving rise to the simple UIRP relation:

$$
i_{t}-i_{t}^{*}=S_{t+1}-S_{t}
$$

Where $i_{t}$ is the interest rate obtainable domestically, $i_{t}^{*}$ is foreign interest rate obtain on assets of similar value, $S_{t}$ is the spot exchange rate for today and $S_{t+1}$ is the spot exchange rate expected one period ${ }_{t+1}$ (one month hence) into the future. UIRP theorizes a depreciation of the currency of the country with higher interest rate to equalize interest rate differential between the two countries. Equation (4) is empirically tested using spot cross exchange rate and expected cross rate of the Nigeria naira and the Botswana pula and the difference in interest rates between the two countries to either uphold or reject the UIRP theory. Similar test is conducted for the other selected African countries still from the Nigeria perspective.

\subsection{Model Specifications and Hypothesis}

A basic tenet and most important assumption of UIRP is the efficient market hypothesis where prices should fully reflect all information available on the market to market participants. Related to this is the assumption of risk neutrality which implies that profitable arbitrage opportunities cease to exist as risk neutral- investors become indifferent between yields on domestic naira assets and return on similar assets abroad (for example Botswana in this case) as exchange rate is expected to adjust such that naira return on domestic asset is equal to naira returns in Botswana giving rise to:

$$
\left(1+\dot{i}_{\aleph}\right)=E_{t}\left(S_{\mathrm{Nt}+\mathrm{K}}\right)^{\mathrm{e}} 1+\hat{i}_{\mathrm{P}}^{*}
$$


Where:

$E_{t}\left(\mathrm{~S}_{\mathrm{N} t+\mathrm{K}}\right)^{\mathrm{e}}=$ the expected future spot cross rate of the Naira at time $t+k$, $\mathrm{k}$ being the number of periods into the future.

$\mathrm{S}_{\mathrm{Nt}}=$ the current naira cross spot rate at time $t$

$i_{\mathbb{N}}=$ current domestic interest rate in Nigeria

$\mathfrak{i}_{\mathrm{P}} *=$ the pula interest rate in Botswana (foreign interest rate)

If an investor is risk neural then, such an investor could invest either in Nigeria or in Botswana giving rise to equation (6).

$$
\left(i_{\mathrm{Nt}}-\mathfrak{i}_{\mathrm{Pt}}{ }^{*}\right)=E_{t}\left(\mathrm{~S}_{\mathrm{Nt}+\mathrm{K}}\right)^{\mathrm{e}} / \mathrm{S}_{\mathrm{Pt}}
$$

Suppose equation (6) is true, then UIRP should hold, otherwise any deviation from UIRP could be attributed to currency related risk in the absence of currency risk hedge. The interest rate differential between domestic and foreign (that is Nigeria and Botswana) rate, and the expected yield from foreign (Botswana) investment is express as:

$$
\Delta S_{\mathrm{Nt}+\mathrm{K}}^{\mathrm{e}}=\left(i_{\mathrm{Nt}}-i_{\mathrm{Pt}}{ }^{*}\right)+X_{t+K}
$$

Here the term $X_{t+K}$ represent the risk premium demanded from risk adverse investors to compensate for the perceived risk in a giving financial instrument. The term $\Delta S \mathrm{~N}_{t+K}{ }^{e}$ on the right side of equation (6) represents the change investors expect in exchange rate yield at time ${ }_{t+K}$. As long as investors are risk averse a differential premium will always exist between future spot and forward exchange rates such that:

$$
F_{t+k}=S_{\mathrm{N} t+\mathrm{K}}^{\mathrm{e}}+X_{t+K}
$$

Substituting equation (8) in equation (7) we have:

$$
F_{t+k}=S_{\mathrm{N} \mathrm{t}+\mathrm{K}}^{\mathrm{e}}-\left(i_{\mathrm{N} t}-i_{P t}{ }^{*}\right)+X_{t+K}
$$

Re-arranging

$$
S_{\mathrm{N} t+\mathrm{K}}{ }^{\mathrm{e}}-S_{\aleph t}=i_{\mathrm{N} t}-i_{P t}{ }^{*}+X_{t+K}
$$

From equation (10) we have the UIRP testing equation

$$
S_{\mathrm{t}+\mathrm{K}}{ }^{\mathrm{e}}=\alpha_{0+} \beta_{1}\left(i_{\mathrm{N} t}-i_{P t}{ }^{*}\right)+\varepsilon_{t+K}
$$

In equation (11) the term $S \mathrm{~N}_{\mathrm{t}+\mathrm{K}}{ }^{\mathrm{e}}$ is the expected future spot rate from time (t) to $(t+k)$. The right hand side of the equation $i{ }_{t}-i_{P t}{ }^{*}$ is the interest rate differential between Nigeria and Botswana and $\varepsilon_{t+K}$ is the forecast error. In the test, it is expected that the slope coefficient $\beta_{l}$ will be equal to 1 and the constant term equal to 0 , otherwise UIRP does not hold. This paper examines the applicability of the theory of UIRP to African countries. Equation 11 is modeled to test UIRP for a single country, and cannot be apply to simultaneously test a cross country study with cross sectional units. Five African countries: Botswana, Egypt Ghana, Kenyan and Nigeria serving as the home country. This gives rise to data that has both pool time series and cross sectional units following which equation 11 is replaced with panel equation 12 to account for the pool structure of the data:

$$
\begin{aligned}
Y_{\text {it }} & =\beta_{1}+\beta_{2} X_{2 i t} \beta_{3} X_{3 i t}+v_{\text {it }} \\
& \mathfrak{i}=1,2,3,4,5 \\
& \mathbf{b}=1,2, \ldots \ldots \ldots 120
\end{aligned}
$$

Here $i$ is taken to be the $i^{\text {th }}$ cross sectional unit, $t$ the $t^{\text {th }}$ for the time period. The X's are not stochastically distributed. Equation (12) represents the fixed effects model of pool data analysis. The assumption is that all pooled time series of the cross section have a common slope and constant intercept since UIRP holds only if $\beta_{1}$ is zero and $\beta_{2}$ is one. $v_{\text {it }}$ follows the normal classical regression assumption - is normally distributed such that $E\left(v_{\mathrm{it}}\right) \sim \mathrm{N}\left(0, \sigma^{2}\right)$. Following Grunfeld (1958), equation 12 is restated as in equation 13:

$$
E X d_{i t}=\alpha+\beta_{1} I R d_{i t}+v_{i t}
$$

Where $E R d_{i t}$ denotes exchange differential between Nigeria and country $i$ at (Botswana, Ghana, Kenyan and Egypt) in month $t, I R d_{i t}$ is the interest rate differential between Nigeria and the $i$ country in month $t$. These panel data consist of 5 (cross sectional units) countries Nigeria as the home country for 10 years 2003-2012. To capture variations that may affect 91 - Day TB rates in the different countries, the fixed effects model of panel equation as in 12 is adopted. Capital movement restriction as was the case in Nigeria until July 2011 is an example of such macroeconomic variations that may affect the 91- Day TB rates. Others may be changing fiscal policies that affect corporate tax rates, liquidity in the economy, inflation etc. 


\subsection{Hypothesis}

By equation (12) to empirically test UIRP we express the null hypothesis as:

$$
\mathrm{H}_{\mathrm{o}}=\alpha_{\mathrm{o}}=0 \text { and } \beta_{1}=1 \text {. }
$$

A-priori it is expected that the joint slope coefficients will to be unity and the incept zero for interest parity to hold amongst the five African countries

\subsection{Unit Root Test}

Following econometric convention the series $E X d_{i t}$ and $I R d_{i t}$ are individually tested for unit roots. It is argued that the presence of unit in a series violates one of the fundament assumptions - the residuals $v_{t}$ follows: $N \sim\left(0, \sigma^{2}\right)$ of the classical regression. Economic time series are generally venerable to non-stationarity. Legislatives changes also economic growths resulting from technological advancement ensure circular trends in many time series data. (Hendry and Juselins 1999), (Mahadeva and Robinson 2004). A regression done with non-stationary series could be spurious giving good residual statistics and coefficients estimates that are not true. It is therefore naturally to test for stationarity to ascertain the true state of a time series data.

Unit root problem in economic time series data is not monolithic as it varies. It is important to rightly ascertain the type of unit root present in a series: heteroscedastic or stochastic deterministic random trend non-stationary unit root induced by cumulative past effects (ibid). Correctly determining the unit root process aids choice of $t$ statistic test to be administered. Stochastic non-stationary allows different trends (negative or positive) at every point in time. Both short term interest rate and exchange rate time series data obtained for this work are prone to stochastic deterministic random trend non-stationarity by nature. Short term interest rates change rapidly and so does exchange rates. They do not trend but change sharply either positively or negatively and thus follow the stochastic deterministic trend non-stationary process. The general form equation is:

$$
\chi_{\mathrm{t}}=\alpha x_{\mathrm{t}-1}+\beta_{\mathrm{t}}+\varepsilon_{\mathrm{t}}
$$

Where the trend is given by $\beta_{\mathrm{t}}$ and the autoregressive element by $\alpha$. Subtracting $\beta_{t}$ from each observation de-trend the series so that equation 14 becomes:

$$
\chi_{\mathrm{t}}=\alpha x_{\mathrm{t}-1}+\varepsilon_{\mathrm{t}}
$$

Equation 15 is the basis of the Augmented Dickey - Fuller test statistics.

The cross sectional unit graphs in Figure 1 below detail this pattern.

EGT Residuals

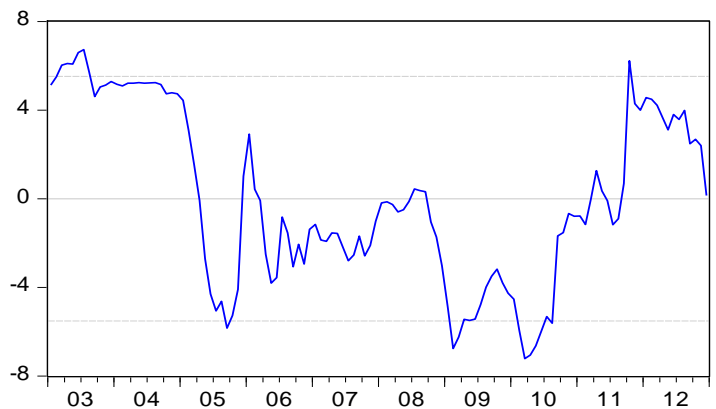

GHA Residuals

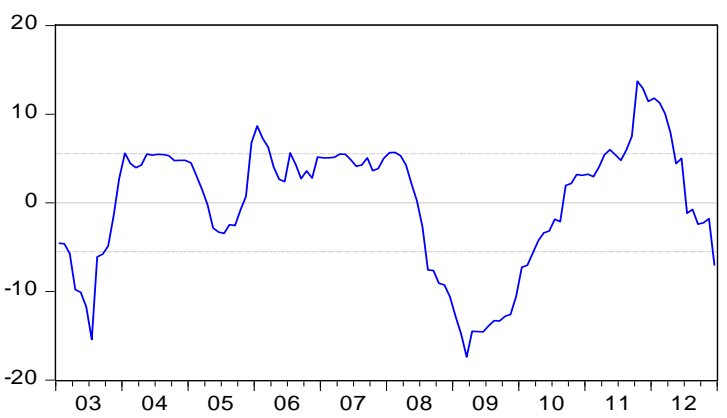

KYA Residuals

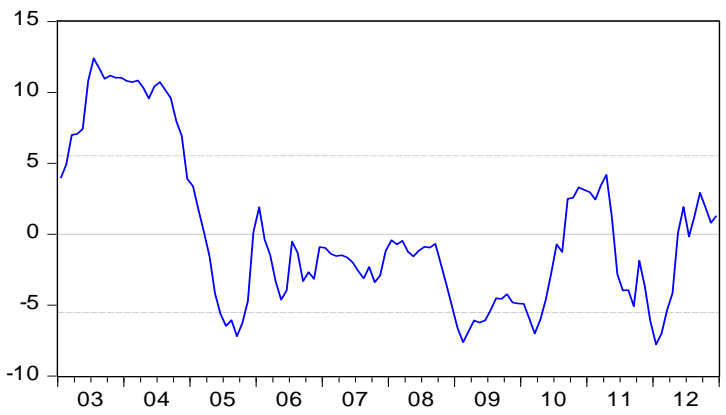

BSN Residuals

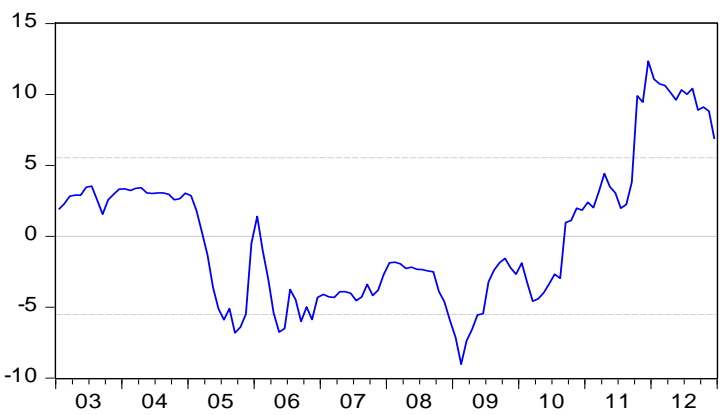

Figure 1. Individual cross sectional residual graphs 
These cross-sectional residual graphs virtually indicate the presence of unit roots in the series for each cross section. It prompts the need to formally test for stationary process and perhaps integration order of the series.

Besides the problem of spurious regression, stationary process and unit root tests are important in an empirical work of this magnitude to know the order of integration in the long run relationship of the variables for setting up the correct econometric model and the generating the right inference (Sjö 2008). Additionally applying ordinary least square regression (OLS) on non-stationary data naturally will result in misleading parameters estimates of the relation (Mahadeva and Robinson 2004) and wrong inference and forcast.

A large number of tests Levin - Lin (1993), Levin - Lin - Chu (2002), Phillips - Su (2003) etc. exist to test for unit root and stationarity in both single series data and panel based data (Lyócsa, Výrost and Baumöhl 2011.see Table 3). The Im, Pesaran and Shin (IPS 2003) unit root test for panel data is often recommended. This test is based on the average of an augmented Dickey-Fuller which is computed for each panel unit (Osbat 2004). The IPS panel unit root test follows the equation:

$$
\mathrm{y}_{\mathrm{i}, \mathrm{t}}=\alpha_{\mathrm{i}}+\rho_{\mathrm{i}} \mathrm{y}_{\mathrm{i}, \mathrm{t}-1}+\varepsilon_{\mathrm{i}, \mathrm{t}}
$$

The $\mathrm{H}_{0}$ all-time series have a unit root, $\mathrm{H}_{1}$ : some time series are stationary

The 91 - Day TB rate differential and exchange rate differential in equation (13) was tested using the IPS (2003) unit root test procedure. The IPS follows The $\mathrm{H}_{0} t_{\text {bar }}$ statistics.

Table 2. Summary of Panel Unit Root Test

Null Hypothesis: Unit root (individual unit root process)

Series: IRDEGT, IRDKYA, IRDGHA, IRDBSN, EXDEGT, EXDKYA, EXDGHA,

EXDBSN

Date: 08/08/13 Time: 07:17

Sample: 2003M01 2012M12

Exogenous variables: Individual effects

User-specified lags: 0

Total (balanced) observations: 952

Cross-sections included: 8

\begin{tabular}{lcll}
\hline \hline Method & & Statistic & Prob.** \\
\hline Im, Pesaran and Shin W-stat & & 0.5421 & 0.7061 \\
Im, Pesaran and Shin t-bar & & -1.3677 & \\
\hline T-bar critical values ***: & $1 \%$ & -2.2300 & \\
& level & 0 & \\
& $5 \%$ & -2.0233 & \\
& level & 3 & \\
& $10 \%$ lev & -1.9200 & \\
& el & 0 & \\
\hline \hline
\end{tabular}

** Probabilities are computed assuming asymptotic normality

*** Critical values from original paper

Intermediate $\mathrm{ADF}$ test results

\begin{tabular}{cccccccc}
\hline \hline & & & & & & Max \\
Series & t-Stat & Prob. & E(t) & E(Var) & Lag & Lag & Obs \\
\hline IRDEGT & -1.0117 & 0.7476 & -1.532 & 0.735 & 0 & 0 & 119
\end{tabular}




\begin{tabular}{llllllll} 
IRDKYA & -1.0372 & 0.7383 & -1.532 & 0.735 & 0 & 0 & 119 \\
IRDGHA & -1.6670 & 0.4454 & -1.532 & 0.735 & 0 & 0 & 119 \\
IRDBSN & -1.2331 & 0.6584 & -1.532 & 0.735 & 0 & 0 & 119 \\
EXDEGT & -1.9137 & 0.3251 & -1.532 & 0.735 & 0 & 0 & 119 \\
EXDKYA & -1.5437 & 0.5081 & -1.532 & 0.735 & 0 & 0 & 119 \\
EXDGHA & -1.5912 & 0.4839 & -1.532 & 0.735 & 0 & 0 & 119 \\
EXDBSN & -0.9441 & 0.7710 & -1.532 & 0.735 & 0 & 0 & 119 \\
\hline Average & -1.3677 & & -1.532 & 0.735 & & & \\
\hline \hline
\end{tabular}

The computed IPS statistics (-1.36771) in Table 2 above appears lower than the critical values: - " $\mathbf{t}_{\text {bar" }}$ " $(-1.9200$, $-2.02333,-2.23000$ at the $10 \%, 5 \%$ and $1 \%$ significant levels respectively). Following this result we cannot conclude to reject the null hypothesis even at the $10 \%$ level. That means the 91-Day TB rate differentials and exchange rate differentials have unit roots problem and are non - stationary series. The IPS does not have strong power; therefore we confirm our finding with the ADF test as in Table 3 below.

Table 3. Summary of Panel Unit Root Test

Null Hypothesis: Unit root (individual unit root process)

Series: IRDEGT, IRDKYA, IRDGHA, IRDBSN, EXDEGT, EXDKYA, EXDGHA,

EXDBSN

Date: 08/12/13 Time: 22:24

Sample: 2003M01 2012M12

Exogenous variables: Individual effects

User-specified lags: 2

Total (balanced) observations: 936

Cross-sections included: 8

\begin{tabular}{ccc}
\hline \hline Method & Statistic & Prob.** \\
\hline ADF - Fisher Chi-square & 13.6603 & 0.6240 \\
ADF - Choi Z-stat & 0.29828 & 0.6173 \\
\hline \hline
\end{tabular}

** Probabilities for Fisher tests are computed using an asymptotic Chi -square distribution. All other tests assume asymptotic normality.

Intermediate ADF test results IRD? EXD?

\begin{tabular}{ccccc}
\hline \hline & & & & \\
Series & Prob. & Lag & Max Lag & Obs. \\
\hline IRDEGT & 0.8708 & 2 & 2 & 117 \\
IRDKYA & 0.8649 & 2 & 2 & 117 \\
IRDGHA & 0.7126 & 2 & 2 & 117 \\
IRDBSN & 0.8288 & 2 & 2 & 117 \\
EXDEGT & 0.1493 & 2 & 2 & 117 \\
EXDKYA & 0.2170 & 2 & 2 & 117 \\
EXDGHA & 0.1615 & 2 & 2 & 117 \\
EXDBSN & 0.4644 & 2 & 2 & 117 \\
\hline \hline
\end{tabular}


The $p$-value in the ADF test result shows that the $2^{\text {nd }}$ lag of the exchange rate differentials and 91 -Day TB rate differentials are not stationary and we cannot conclude to reject the null hypothesis. This implies that exchange differentials and 91 -Day TB rate differential have a unit root. The unit root test conducted as in Table 4.1 and 4.2 indicates the consistent presence of unit roots in the series $E X d_{i t}$, and $I R d_{i t}$ - both are stochastic deterministic trend non-stationary time series data.

\subsection{Panel Cointegration Test}

Theory says many financial variables "contains one unit roots and are thus I(1)"..... and many times, series that are non-stationary move together over time (Brooks, C. 2008). Cointegration implies long run relationship amongst variables and a test for cointegration is only necessary if the series are non-stationary. The Panel unit root test results in Tables 2 and 3 confirm the presence of unit root in the series exchange rate and 91-T Bill rate differentials and provide the basis for a panel cointegration test.

Table 4. Johansen Fisher Cointegration Test

Johansen Fisher Panel Cointegration Test

Series: IRD? EXD?

Date: 10/23/13 Time: 16:42

Sample: 2003M01 2013M12

Included observations: 132

Trend assumption: Linear deterministic trend

Lags interval (in first differences): 11

Unrestricted Cointegration Rank Test (Trace and Maximum Eigenvalue)

\begin{tabular}{|c|c|c|c|c|}
\hline $\begin{array}{l}\text { Hypothesized } \\
\text { No. of CE(s) }\end{array}$ & $\begin{array}{c}\text { Fisher Stat.* } \\
\text { (from trace test) }\end{array}$ & Prob. & $\begin{array}{c}\text { Fisher Stat.* } \\
\text { (from max-eigen test) }\end{array}$ & Prob. \\
\hline None & 69.34 & 0.0000 & 72.49 & 0.0000 \\
\hline At most 1 & 13.67 & 0.0335 & 13.67 & 0.0335 \\
\hline \multicolumn{5}{|c|}{$\begin{array}{l}\text { * Probabilities are computed using } \\
\text { asymptotic Chi-square distribution. }\end{array}$} \\
\hline \multicolumn{5}{|l|}{ Individual cross section results } \\
\hline Cross Section & $\begin{array}{l}\text { Trace Test } \\
\text { Statistics }\end{array}$ & Prob.** & $\begin{array}{l}\text { Max-Eign Test } \\
\text { Statistics }\end{array}$ & Prob.** \\
\hline \multicolumn{5}{|l|}{ Hypothesis of no cointegration } \\
\hline EGT & 57.3810 & 0.0000 & 56.4123 & 0.0000 \\
\hline KYA & 61.2923 & 0.0000 & 53.3339 & 0.0000 \\
\hline GHA & \multicolumn{4}{|c|}{ Dropped from Test } \\
\hline BSN & 4.4250 & 0.8664 & 4.2655 & 0.8303 \\
\hline \multicolumn{5}{|c|}{ Hypothesis of at most 1 cointegration relationship } \\
\hline EGT & 0.9687 & 0.3250 & 0.9687 & 0.3250 \\
\hline KYA & 7.9584 & 0.0048 & 7.9584 & 0.0048 \\
\hline GHA & \multicolumn{4}{|c|}{ Dropped from Test } \\
\hline BSN & 0.1595 & 0.6896 & 0.1595 & 0.6896 \\
\hline
\end{tabular}

**MacKinnon-Haug-Michelis (1999) p-values 
Using the Johansen Fisher (1988) panel cointegration test, we test for cointegration relationship in in the series $E X d_{i t}$ $=\alpha+\beta_{1} I R d_{i t}$. The Johansen Fisher panel cointegration test two different null hypothesis: 1$)$ the likelihood ratio trace statistics or trace test and 2) the maximum eigenvalue statistics. These test statistics are computed as in equations 17 and 18 shown below.

$$
\begin{gathered}
\lambda \operatorname{trace}(r)=-T \sum_{i=r+1}^{n} \ln (1-\lambda i) \\
\lambda_{\max }(\mathrm{r}, \mathrm{r}+1)=-T \ln \left(1-\lambda_{\mathrm{r}+1}\right)
\end{gathered}
$$

Where $\mathrm{T}=$ is the sample size

$$
\lambda=\text { is the maximum eigenvalue }
$$

The likelihood ratios trace statistics test the null hypothesis of $r$ cointegrating relations against the alternative of a full rank $\mathrm{r}=n$ cointegrating relations. The maximum eigenvalue statistics test the null hypothesis of $\mathrm{r}$ cointegration vectors against the alternative of $\mathrm{r}+1$.

\section{Result and Discussion}

The Johansen Fisher cointegration test statistics in Table 4.3 rejects the null hypothesis of no cointegration. There is a cointegrating relation as indicated the in the summary of the Johansen Fisher test statistics in. This means there exist a long run relationship between interest rate and exchange rate across some African countries - bilateral exchange rate adjust to equalize interest rates. In other words Uncovered Interest Rate Parity (UIRP) - that is, the equality of interest rate across different countries due to adjustment in bilateral exchange rate holds amongst some of the selected countries in African. However the result is not total and further studies is needed to draw a comprehensive conclusion.

\section{References}

Arias, G. (2001). Deviations from Uncovered Interest Parity, lessons to be drawn from currency crises models. Centre d'Economie et de Finances Internationales (CEFI) Château Lafarge, 13400 Les Milles, France. Working Paper series No. 2001/07.

Asari, F.A.H., et al. (2011). A Vector Error Correction (AECM) Approach in Explaining the Relationship Interest and Inflation towards Exchange rate Volatility in Malaysia. World Applied Science Journal 12(Special Issue on Bolstering Economic Sustainability), 49-56.

Backus, D.K, et al. (2010). Monetary Policy and the Uncovered Interest Parity Puzzle. NBER Working Paper No. 16218 , July.

Banerjee, \& Carrion-i-Silvestre, J, L. (2006). Cointegration in Panel Data with Breaks and Cross-Section Dependence. Working Paper Series No. 59, February 2006. European Central Bank (ECB).

Brigden, A, et al. (1997). Decomposing Exchange Rate Movements According to the Uncovered Interest Rate Parity Condition. Bank of England Quarterly Bulletin, November, 225-27.

Brooks, C. (2008). Introductory Econometrics for Finance (2 ${ }^{\text {nd }}$ ed.). Cambridge University Press. The Edinburgh Building, Cambridge CB2, 8UR, UK.

Chaboud, A.P., \& Wright, J.H. (2002 and 2003). Uncovered Interest Parity: It Works, But Not For Long. Board of Governors of the Federal Reserve System.

Cholifihani, M. (2008). A Cointegration Analysis of Public Debt Service and GDP in Indonesia. Journal of Management and Social Sciences, 4(2), Fall, 68-81.

Geert, B., Wei, M., \& Xing, Y. (2005). Uncovered Interest Rate Parity and the Term Structure. Columbia Business School, 808 Uris Hall, 3022 Broadway, New York, NY 10027, USA Board of Governors of the Federal Reserve, Division of Monetary Affairs, Washington, DC 20551. USA Jones Graduate School of Management, Rice University, Room 230, MS531, 6100 Main street, Houston, TX 77005, USA.

Harvey, T. (2005). Modeling Interest Rate Parity: A System Dynamics Approach. Working Paper Nr. 05 - 01. Texas Christian University Fort Worth, Texas 76129.

Harvey, T. (Undated paper). Deviations from Uncovered Interest Rate Parity: A Post Keynesian Explanation. Texas Christian University Fort Worth, Texas 76129.

Hendry, D.F., \& Juselius, K. (1999). Explain Cointegration Analysis Part I. Unpublished paper Department of Economics. Oxford University UK and University of Copenhagen - Denmark. 
Hendry, D.F., \& Juselius, K. (2000). Explaining Cointegration Analysis Part II. Unpublished paper Department of Economics. Oxford University UK and University of Copenhagen - Denmark.

Juhl, T., Miles, W., \& Weidenmier, M.D. (2004). COVER INTEREST ARBITRAGE THEN VS. NOW. NBER, 1050 Massachusetts Avenue Cambridge, MA 02138. Working Paper Series 10961. http://www.nber.org/papers/w10961

Lada, K., \& Wöjcik, P. (2007). VEC Model - the Influence of Export on Economic Growth. Unpublished Macroeconomics handouts. Class Notes.

Lopez, C. (2004). An Improved Panel Unit Root Test Using GLS-Detrending. University of Cincinnati, August.

Lothian, R.L., \& Wu, L. (2002 and 2005). Uncovered Interest-Rate Parity over the Past Two Centuries. Graduate School of Business, Fordham University Zicklin School of Business, Baruch College.

McCosky, S., \& Kao, C. (1999). Comparing Panel Data Cointegration Test with an Application to the "Twin Deficits" Problem. Retrieved from http//web.syr.edu/-cdkao

Moosa, I. (2011). The Failure of Financial Econometrics: Assessing the Cointegration Revolution. The CAPCO Journal of Financial Transformation Journal, 32.

Morshed, H.A.S (undated M.Sc. thesis). A Panel Cointegration Analysis of the Euro Area Money Demand. Lund University, School of Economics and Management.

Paul, R.K .(undated). Econometric Analysis Using Panel Data. IASRI Library Avenue, New Delhi - 110012.

Ray, S. (2012). Testing the Validity of Uncovered Interest Rate Parity in India. Advances in Applied Economics and Finance (AAEF), World Science Publisher, United States, 1(4), 236,

\section{Newspaper}

Iheanyi Nwachukwu. (2013). 15 April, Business Day, p. 7.

\section{Sources of Time Series Data}

Bank of Botswana. Retrieved from www.bankofbotswana.bw/index.php/conter

Bank of Ghana. Retrieved from www.bog.gov.gh/index.php?option=com_w

Central Bank of Nigeria. Retrieved from www.cenbank.org./Rates/financial Data.as

Historical Exchange (monthly) rates. Retrieved from www.fxtop.com

Retrieved from Central Bank of Egypt - www.cbe.org.eg/English/liquidity/

Retrieved from Central Bank of Kenya - www.centralbank.go.ke/index/php/time-series 